\title{
An International Comparison of Education Research Policies
}

\author{
Yung-Ming Shu ${ }^{\mathrm{a}, *}$ \\ ${ }^{a}$ National Tsing-Hua University, Taiwan
}

\begin{abstract}
This is a comparative study of the education research policies in several countries and international organizations. The purpose of the comparison is to discover the trends in this field. Four dimensions are used for education research policy: the aims of education research, the promoted research methods, the priority areas in education research, and databases for education research. These dimensions need direction and support from government. The findings are that public interest is pursued by education research institutes. However, any research result that runs counter to current policies will be suppressed. Stakeholders, such as sponsors, researchers and journals, do not take public interest as their main concern. The most promoted method in education research is evidence-based research because it is thought to be more useful and reproducible. The priority area for education research, however, is not so evident. But basic research and new areas, like neuroscience and popular culture, are more common. There are databases for education research in many countries. PISA of OECD is the most conspicuous one in recent years. Education research and educational policy is interwoven together. Education research can contribute to educational policy, while educational policy many direct the orientation of education research. Each should have the other in mind.
\end{abstract}

\begin{abstract}
Abstrak
Makalah ini merupakan studi komparatif atas kebijakan penelitian pendidikan di beberapa negara dan organisasi internasional. Tujuan komparasi ini adalah untuk mengidentifikasi berbagai tren di bidang penelitian pendidikan. Ada empat aspek yang diaplikasikan dalam kebijakan penelitian pendidikan, yaitu: tujuan penelitian, metode penelitian yang ditawarkan, prioritas area, dan bank data penelitian pendidikan. Aspek-aspek ini membutuhkan arahan dan dukungan dari pemerintah. Studi ini menemukan, bahwa banyak lembaga penelitian pendidikan yang mengacu atau berorientasi pada kepentingan publik. Namun, temuan penelitian yang berlawanan dengan kebijakan terkini sengaja tidak ditonjolkan. Sementara kelompok pemangku kepentingan yang lain, seperti sponsor, peneliti dan jurnal, tidak menjadikan kepentingan publik sebagai acuan utama. Metode yang paling banyak ditawarkan adalah penelitian berbasis bukti faktual, karena dianggap lebih bermanfaat dan bisa diduplikasi. Prioritas area di penelitian pendidikan tidak terlalu jelas. Namun penelitian dasar dan bidang-bidang baru makin banyak, seperti neurosains dan budaya popular. Ada beberapa bank data penelitian pendidikan dari beberapa negara. PISA dari OECD paling menonjol tahun-tahun belakangan ini. Penelitian pendidikan dan kebijakan pendidikan saling terkait. Penelitian pendidikan dapat berkontribusi pada kebijakan pendidikan, sedangkan kebijakan pendidikan dapat menjadi orientasi penelitian pendidikan. Sudah semestinya masing-masing harus saling mengakomodir.
\end{abstract}

Keywords: Education Research Policies, Policy Analysis, Research Prioritization, Educational Research, Education Research Databases

\section{Introduction}

The policy on education research is seldom talked issue. It can be easily confused with educational policy. However, they are interwoven. Theoretically, educational policy should be made according to the principles from the outcome of education research. But it is often the case that educational policy steer the direction of edu-

*Corresponding author. Address: National Tsing-Hua Univercation research. Here, education research means that countries or sity, Taiwan. Email: yms47@ms52.hinet.net. international organizations sponsor and steer education research 
which is different from the research by non-governmental organizations. In reviewing education research policy, we can see the specter of educational policy under the table. Education research can seldom have total autonomy.

A good research policy includes many facets. It can be broadly defined as whether to establish a research institute or just sponsor research by aides to applicants. Most education researches are conducted in higher education institutions. What measures or indicators are used to evaluate and who are suitable for the evaluation are also decided by research policy. To what extent does research performance of university staff members contribute to their promotion processes. One of the infrastructures of education research is the establishment of a databank for raw data which make latitudinal research possible. Government plays an important role in the processes of data collecting.

The above issues are themes of our research team, whose individual papers are also included in this special issue. Therefore, education research policy in this article is narrowly defined as not to be overlapped with them. These include the aims of education research of the government of national research institute, the promotion of research methods, the priority areas of education research, and the establishment of research databank for raw data. The aims of the education research decide the orientation. But ministries of education, as the general implementing agency of policy, may interfere in the direction of education research. Other stakeholders in education research, such as researchers and journal editors, may deviate from government official approaches. The promotion of research methods and priority areas of research may contradict with freedom of research. However, governments often want to manipulate the orientation of education research. The last part of this paper focuses on the establishment of databank for research.

There are obstacles in this research paper. The method adopted is mainly document analysis. Data referred to come primarily from several different countries and international organizations. Primary document sources are referenced and in some cases summarized.

\section{The Declared Aims of Research Institutes: The Public Interest}

The legitimate primary concern of education research should be the public interest. And research policy often defines what is considered in the public interest. Even when the concern for public interest is certain, there are many factors that sometimes stand in the way as obstacles; among those who generate rationales for these obstacles include research sponsors, scientists, and journal editors. These stakeholders often have their own interests. And the outcomes can be seen from their choice of research topics, methods, etc. A brief discussion of the aims will be presented first, followed by a discussion of these obstacles.

\section{Education Research Aims in Various Countries and Interna- tional Organizations}

\section{United States of America}

The National Research Coucil of the U.S. Government has five divisions. Education research is situated in the Behavioral and Social Sciences and Education division, which has a mission to: advance the frontiers of the behavioral and social sciences and their applications to public policy.

The goal of our work is to provide independent, evidence-based advice to decision-makers on key questions of national importance, such as:

*What is the best way to measure levels of poverty in the United States?

*How do parents, teachers, and policymakers know how well students are learning?

*How can the public participate most effectively in decisionmaking about the environment?

*Why does life expectancy differ greatly among high-income countries, and how can the answer to that question help increase the life expectancy of Americans in the future? (NRC 2014)

\section{United Kingdom}

The UK has seven research councils, which are put together as the Research Councils UK (RCUK). Education research is situated in the Economic and Social Research Council (ESRC). In the "Mission and Statement of Expectation on Economic and Social Impact," the mission derived from the Royal Charters of the Research Councils is to build partnerships to enhance take-up and impact, thereby contributing to the:

\section{Economic competitiveness of the United Kingdom}

Effectiveness of public services and policy, and

Enhancement of the quality of life and creative output of the nation. (RCUK 2014)

\section{Australia}

In Australia, the mission of the Australian Research Council (ARC) "is to deliver policy and programs that advance Australian 
research and innovation globally and benefit the community” (ARC 2014).

Japan

In Japan, the National Institute for Educational Policy (NIER) aims to achieve the following objectives as mid-term goals:

1. To present findings obtained from scientific surveys, analysis, and predictions of worldwide situations surrounding education for Japan's future policies. The findings should be used to plan and design strategic educational policies in the mid and long term.

2. To conduct scientific surveys of and analyze the current situation and social background for solutions to urgent political issues. The outcomes should be used to plan and design educational policies that flexibly address social needs.

3. To give help, support and advice about social and school education activities where necessary.

4. To gather, file and store educational information, data, and documents and make them available to interested parties in Japan and abroad.

5. To collect knowledge and promote information sharing for educational research with bodies in Japan and abroad. This can be done by implementing international education cooperation, holding conferences, and conducting joint research studies. (NIER 2014)

\section{France}

In France, the National Center for Scientific Research (CNRS: Centre National de la Recherche Scientifique) was founded in 1939 by governmental decree. CNRS has the following mission:

1. To evaluate and carry out research capable of advancing knowledge and bringing social, cultural, and economic benefits to society.

2. To contribute to the application and promotion of research results,

3. To develop scientific information,

4. To support research training, and

5. To participate in the analysis of the national and international scientific climate and its potential for evolution in order to develop a national policy. (CNRS 2014)

\section{European Union}

In the EU, Horizon 2020-which is the EU Framework Programme for Research and Innovation — spans the time period 2014 to 2020, and has three strategic goals:

1. Excellence in the science base,

2. Industrial leadership, and

3. Societal challenges. (EU 2013)

Addressing societal challenges means solving social problems through interdisciplinary research. The challenges are:

1. Health, demographic change and wellbeing.

2. Food security, sustainable agriculture and forestry, marine and maritime and inland water research and the bioeconomy.

3. Secure, clean and efficient energy.

4. Smart, green and integrated transport.

5. Climate action, environment, resource efficiency and raw materials.

6. Europe in a changing world-inclusive, innovative and reflective societies.

7. Secure societies protecting freedom and security of Europe and its citizens.

In the overview above, the aims can be summed up into three categories: First, the research they defined are mostly "scientific research," that is for practical use, not for the enhancement of knowledge. These researches should be evidence-based, and can be used for decision-making (i.e., much related to educational policy). Therefore, it comes the problem whether educational policy decides education research or the outcomes of education research direct educational policy. Second, the "scientific" character also means the research should contribute to economic development or enhance industrial competitiveness. The public interest here is defined in capitalistic terms. Third, these aims are extrinsic for education. This is because the policies are defined from the viewpoint of a nation. From the viewpoint of education, they are extrinsic that make education a tool for other aims. The intrinsic aims should be the wellbeing of human being. But these aims also determine what kind of project will be financed. It is quite evident those with no immediate practical use will be sacrificed.

\section{Sponsoring Individuals and Organizations}

Sponsoring individuals and organizations will dominate the direction or the results of the research. Even when money is from 
public funds, the government does not like the results to contradict its policies. The Department of Education or the National Research Institutes may be the most powerful sponsors in distributing research budgets and controlling the research institutes. Any result that contradict their policies will be prohibited. The following are the case of Research Contract Terms and Conditions for the Department for Education of the UK government. On the publication of research papers, the British Educational Research Association (BERA) has defended the right of researchers in Revised Ethical Guidelines for Educational Research. In Article 39, only six conditions can prevent the publishing of a research paper:

1. Researchers have waived this right in writing;

2. Publication would contravene the law (e.g., in the area of libel or race relations);

3. The work has been commissioned specifically to produce a confidential report (e.g., consultancy reports that are based on research activity);

4. Undertakings have been given to participants concerning confidentiality and the intention to avoid causing unnecessary harm to those affected by the research findings; or

5. The researchers have failed, without reasonable justification, to report findings in a manner consistent with the ethical guidelines (e.g., failure to report findings honestly and accurately). (BERA 2004, pp. 11-12)

In other words, there are only restrictions for ethical reasons. But the research contract with the British government hold sway over publication.

26.4 The Contractor shall consider revisions to the drafts with the Project Manager in the light of the Department's comments. The Contractor shall provide final, signed off interim reports and other outputs planned within the lifetime of the Project to the Department by no later than four weeks before the intended publication date, and final, signed off reports and other outputs at the end of the Project to the Department by no later than the contracted end date for the Project.

26.2(sic: 26.5) Until the date of publication, findings from all Project outputs shall be treated as confidential, as set out in the Clause 13 above. The Contractor shall not release findings to the press or disseminate them in any way or at any time prior to publication without approval of the Department.

26.3(sic: 26.6) Where the Contractor wishes to issue a Press Notice or other publicity material containing findings from the Project, notification of plans, including timing and drafts of planned releases shall be submitted by the Contractor to the Project Manager at least three weeks before the intended date of release and before any agreement is made with press or other external audiences, to allow the Department time to comment. (Department for Education 2013, p. 24)

In the above clauses, the Department can veto any public release of the research. The sponsor's comment is the last judge. But it seems that the judgement is unconditional.

There is no principle for the commentator to abide by. If the Department is to defend the public interest, the interest of the Department becomes public interest. Simmons has pointed out a case of this kind that is a research on national curriculum. The paper failed to publish because the conclusion is not accepted by the Department (Simmons 1995, p. 437).

\section{Researchers and Journal Editors}

For the researcher, the public may not be the main concern in the choice of topics. For research credit, to get published is the most important goal. But the quality of the paper, not for the public, is decisive for its acceptance by a journal. In Taiwan, we have the criteria of the Science Citation Index (SCI), Social Science Citation Index (SSCI), and the Taiwan Social Science Index (TSSCI). The articles on accepted for publication in these journals will get the highest recognition in promotion and tenure reviews. Taiwan was ranked 23rd in SCI/SSCI production in 2003. In 2009 and 2010, Taiwan increased its global ranking to 19 (NSC 2013). SCI and SSCI are foreign standards in which Taiwan's interest is not the major concern. That means our articles have reached the international level. In this sense, public interest does not mean much for the researcher. It is only one of the indicators in evaluating the quality of the article.

In the review of research quality in top-tier British educational journals, Tooley and Darby (1998) point out that the relevance of research for policy and practice is tenuous, even in the case of action research. There were no examples of replication of research. It means that there is no accumulation of knowledge. The researchers are working in a vacuum.

\section{Choice of Research Topics}

Research topics have much to do with conducting research in the public interest. But that is also restricted by what sponsors want to fund. The controversy is often regarding what is the question of the "public interest." If one's view of social justice is different from the government's official, policy-based view, the legitimacy of research 
topics will be quite different. Anyon (2006, pp. 22-24) has raised the following topics for American education research:

1. Document and describe oppression

2. Study the powerful

3. Assess efforts of urban communities to create power and opportunity

4. Study social movements

5. Study student activists

6. Investigate ways to make schools movement-building spaces

The above topics often run against the current. Some of these topics seldom emerge in education research. One of the reasons is that sponsors will not always subsidize research to criticize its own interests. Another reason is that some research findings may easily contradict public and private-sector policies. For example, there is seldom negative research conducted on the effectiveness of cram schools or private schools in Taiwan. Also, there is seldom research on criticism of public schools in the UK. However, these taboo topics may have much to do with what constitutes public interest. But as a researcher, it is often too heavy a burden to fight for social justice just with one's own might.

In the above analysis, the author is entitled to be pessimistic as there are so many obstacles for education research to pursue public interest. In the declarations of research institutes, public interest is the legitimate aim. But for sponsors, researchers and journals, public interest is not the main concern that can be discerned from the topics of education research.

\section{Methods Promoted in Educational Research}

In Germany, the Federal Ministry of Education and Research (BMBF) issued its Framework Program for the Promotion of Empirical Educational Research (BMBF 2008), which promotes evidence-based education policy. In education research, there should be an empirical revolution. The following strategies are adopted:

1. Scientifically based conclusions regarding the effective mechanisms underlying teaching and learning processes;

2. A co-ordinated system of national and international performance studies;

3. The development of usefully co-ordinated system of regular (internal and external) evaluations and feedback, on the various relevant system levels and in connection with newly introduced reform measures; and

4. A high quality system of education statistics. (p. 25)
In the UK, the Department for Education established The Evidence for Policy and Practice Information and Co-ordinating Centre (EOOI-Centre) in 1993 in the Institute of Education (IOE), at the University of London). It focuses on two areas:

1. Systematic reviews: This includes developing methods for systematic reviews and research syntheses, conducting reviews, supporting others to undertake reviews, and providing guidance and training in this area.

2. Research use: This includes studying the use/non-use of research evidence in personal, practice and political decisionmaking, supporting those who wish to find and use research to help solve problems, and providing guidance and training in this area. (EPPI-Centre 2009)

The evidence is supposed to make research replicable; that is the criteria of the natural sciences. In Britain, "evidence-based," "cumulative,” "cumulative knowledge,” and generalization” are catch words that emerge quite often in these reviews. What they promote implicitly is positivism. Phil Hodkinson (2004) has pointed out that "evidence-based research" has becomes a new orthodoxy in education research. He maintains that a diversity of methods in education research is more desirable.

In America, the National Research Council (NRC) published the Scientific Research in Education in 2002. There are six principles of scientific research outlined in this document:

1. Pose significant questions that can be investigated empirically

2. Link research to relevant theory

3. Use methods that permit direct investigation of the question

4. Provide a coherent and explicit chain of reasoning

5. Replicate and generalize across studies

6. Disclose research to encourage professional scrutiny and critique. (NRC 2002, pp. 3-5)

The scientific research defined above is not only empirical, but also has theoretical basis. It also has good characteristics of a good research as coherent, generalizable, and critical. These requirements are too perfect to be true! It is very difficult for education research to be macro (generalizable) and micro (exact) at the same time.

In the Organisation for Economic Co-operation and Development (OECD), the Centre for Educational Research and Innovation (CERI) promoted evidence-based policy research in 2003, and published Evidence in Education: Linking Research to Policy (CERI 2007). The preferred research method is "experimental designs, and especially that of randomized control trials, should be given a 
stronger role, though they differ on their exact place in the range of research instruments” (pp. 9-10). The method promoted is an imitation from natural science. But education research is for whole person. Only a few topics can be experimented like exact science.

The European Educational Research Quality Indicators (EERQI) were developed by the EU to counter the SSCI of the American publishing group Thomson Reuter. SSCI is too one-sided, where roughly 89 percent of publications are in English, 52 percent of journals are based in the US and 24 percent are from the UK (Gogolin 2011, p. 4). EERQI is an ambitious endeavor to overcome the problems of multilingualism in the fields of education research and SSH (social science and the humanities). EERQI intends to be more comprehensive than SSCI as to have internal (rigor, originality, significance, integrity, and style) and external (mostly the existing information about the author and journals) indicators in measuring the quality of education research papers. Semantic analysis is a special tool for helping to judge quality (Gogolin 2011, p. 12). Citation is one of the most important criteria for measuring the quality of a research paper. The motivation author to cite has been break down into five kinds:

1. ARGUMENTATION: argumentation between the citing and the cited work.

2. EVIDENCE: the cited work provides evidence for the cited work.

3. IMPORTANCE: the author of the citing work finds the cited work important.

4. QUALIFICATION: the cited work is qualified by the citing work.

5. SURPRISE: the author of the citing work is surprised by the cited work. (p. 23)

Whether an article be cited or not have much to do with it quality. Research method is one of the elements composing quality. To refine the motivation of a citation will make the counting of citation more correct.

In the final report by Gogolin, EERQI seems so perfect. EERQI is a very comprehensive and specific tool, but there is no mention of which research method maybe preferred. This reflects a possible bias in any quality measurement that should be tested for in the process of conducting a pilot study. Another doubt is raised about the validity of semantic analysis which is very important for theoretical research. Since it is a relatively new tool, its validity is to be seen in the future.

\section{Priority Areas of Education Research}

The choice of priority areas in education research is closely related to the promoted research methods. In the UK, based on evidence-informed policy and practice, the Economic and Social Science Research Council (ESRC) sponsored the Teaching and Learning Research Programme (TLRP) from 2000 to 2011. There were 70 projects with 700 researchers. It was a response to the criticisms of Hargreaves and Hillage (Saunders 2008, p. 2).

Further, ESRC issues an annual Britain in Magazine to focus on research topics. The topics of recent years in education are as follows:

Britain in 2014: The problem of the internet

Britain in 2013: The pursuit of social mobility

Britain in 2012: Measuring social mobility

Britain in 2011: Faith-based schooling in a secular society

Britain in 2010: Body weight up, test results down

Britain in 2009: Educational aspirations among ethnic minorities

Britain in 2008: (no educational issue)

Britain in 2007: Learning to live. (ESRC 2013)

In Germany, the Framework Program for the Promotion of Empirical Educational Research also designates the following priority research areas:

1. Establishment of a national education panel study

2. Competence diagnostics

3. Issues of control and taking account of evaluations at the system's various levels (ranging from the system as a whole to the level of individual institutions)

4. Equal opportunity and participation

5. Optimal design of teaching and learning processes

6. Funding initiative "Neuroscience, Instruction and Learning (NIL)"

7. Professionalisation of teaching staff, and

8. Transfer of knowledge. (BMBF 2008, pp. 35-37)

There is a coincidence as the focus on the sexualization of children. The Australia Institute issued Letting Children be Children : Stopping the Sexualisation of Children in Australia in 2006 (Rush and La Nauze: 2006). Five 5 years later, the British government also reviewed the same topic: Letting Children be Children: Report of an Independent Review of the Commercialisation and Sexualisation of Childhood. (Bailey, 2011). The coincidence shows the seriousness of the problem. Similar researches was also conducted in the UK (Buckingham et al. 2010; Bryon 2008; Papadopoulos 2010). 
These reviews show the urgent problem of the sexualization of children and young people, and their commercialization in the Internet world. This reflects the idea that education research often has to confront social problems from popular culture.

\section{The Establishment of a Research Database}

In evidence-based research, the collection of raw data is a necessity. But some data are in passing. These data should be collected continuously and reserved. For longitudinal research, chronological data are needed. However, the task of data collection can hardly be finished by personal efforts alone. It needs governmental support because the quantity is large enough to be a database. Since many data are personal privacy, it needs the guarantee from government for their use. And these data should be sorted and arranged ready for research. The sanction for a research project to use the database also needs professional decision. Therefore, government support for the establishment of a database for research use is an important task in research policy. Many education research studies cannot be undertaken without the creation of such a database.

The importance of a database in education research is stressed in the conclusion of the Hilliage Report in 1998: "Where the research does address policy-relevant and practical issues it tends to be small scale and fails to generate findings that are reliable and generalisble” (Hillage, Pearson, and Tamkin 1998, p. xi). Their recommendation is

To support policy formation and practice, the research community has to have both a thriving theoretical and applied base which are fit for the purpose they seek to serve. Our assessment is that there is insufficient large-scale applied research in this area. (p. xi)

Therefore, this kind of database is the basic infrastructure for large-scale education research. The following is the existing databases for education in several countries and international organization.

In the United States, the Department of Education has the National Center for Educational Statistics (NCES 2014), a database that contains:

National Education Longitudinal Study (NELS)

National Assessment of Educational Achievement (NAEP), since 1969

National Assessment of Adult Literacy (NAAL), since 1985

Early Childhood Longitudinal Study (ECLS), since 1998

National Household Education Survey (NHES), since 1991

National Education Longitudinal Study (NELS), since 1988
In the UK, there is the National Pupil Database (NPD), which covers the pupils in England from ages 3 to 21. This database dates from 1995 with 16 categories of data:

School Census/PLASC ([ages] 3-18), PRU Census (3-18), Early Years Census (3-4), Alternative Provision (3-16), Early Years Foundation Stage Profile (4), Key Stage 1(6), Key Stage 2 (10), Year 7 Progress Tests (11), Key Stage 3 (13), Key Stage 4 Awarding Body data (14-21), Key Stage 4 Achievement \& Attainment Tables data $(15,14 / 16)$, Key Stage 5 Awarding Body data (14-21), Key Stage 5 Achievement \& Attainment Tables data (16-18), Children Looked After (0-18), Children in Need (0-18), PLAMS (16-18). (Department for Education 2012)

The database is for research use. It contains a National Pupil Database: User Guide with a detailed guide in 40 pages (Department for Education 2017).

The most influential database is the Programme for International Student Assessment (PISA) established by OECD. PISA is the test for 15-year-olds in reading, mathematics and science. Taiwan's performance results are noted below in parenthesis (PISA in Taiwan).

2000 Reading (main), Science, and Mathematics supplement 2003 Mathematics (main), Reading, and Science supplement

2006 Science (main) (4), Reading (16), and Mathematics(1) supplement

2009 Reading (main) (23), Science (12), and Mathematics(5) supplement

2012 Mathematics (main) (4), Reading (8), and Science(13). With Problem Solving as supplement. (PISA in Taiwan 2013)

Shanghai scored at the top in all fields in 2012. PISA is also an important database because with the test of achievements, it also collects related education data. The background questionnaires are for different groups.

The school questionnaire is administered to principals and covers the structure and organization of the school; the student and teacher body; the school's resources; the school's instruction, curriculum and assessment; the school climate; the school's policies and practices; and the characteristics of the principal or designate.

The questionnaire for students addresses their educational career, family context and home resources; individual engagement in reading; instructional time; learning and assessment; classroom and school climate; access to and use of libraries; and students' strategies in reading and understanding texts. 
Two optional questionnaires are administered to students: an educational career questionnaire covering the students' educational histories and career aspirations; and a questionnaire about students' access to information and communication technology and their use of and attitude towards computers.

A third optional questionnaire for parents covers their children's past reading engagement; their own reading engagement; home reading resources and support; parents' background; their perception of and involvement in school; and school choice. (OECD 2009, Annex B)

In 1997, OECD also began the Definition and Selection of Competencies Project (DeSeCo) to find Key Competencies, and now it extends the testing to higher education through the Assessment of Higher Education Learning Outcomes (AHELO) (OECD 2012). It includes generic skills and discipline-specific skills for university students. Performance on PISA has become the focus of education reform in many countries. There is also the phenomenon of "teaching to the test.” Most governments take PISA results seriously. People say there will be "PISA curriculum" in the near future. That's maybe the reason why there is more and more research on PISA.

By the help of computer science, it is easier than before in establishing database for education research, which makes large-scale education research possible. And large-scale research will contribute to a good research as its conclusion is more reliable and generalizable. These conclusions will also enhance the decision-making in educational policy. Therefore, education policy is much related with education research policy.

\section{Conclusion}

From the comparative study, the findings are: first, in the aims of education research, interest is the legitimate ends of education research. But the stakeholders (the sponsor, researcher and journal) do not necessarily take it very seriously. And the "scientific research" defined in the aims are mostly a copy from natural science, that is for economic and other practical use. Education becomes a tool for other purposed. Second, the most promoted method in education research is evidence-based research that is a necessary deduction from the practical aims of education research. Third, the priority area for education research is not so evident. Each country has its own priority. But the basic research and new areas, like neuroscience and popular culture, are more common. Fourth, there are databases for education research in many countries. PISA of OECD is the most conspicuous one in recent years.
In the discussion of education research policy, I can find the specter of education policy hovering above it. Theoretically, educational policy should base its foundation from education research, which will enhance the tenability and practicality of the policy. On the contrary, educational policy can also direct the orientation of education research policy by make research results to support educational policy. In this case, it will become a self-fulfilling prophesy of educational policy. This is not what people want. Education research policy should be given autonomy to counter education policy.

\section{References}

Anyon, Jean. 2006. "What Should Count as Educational Research: Notes toward a New Paradigm.” In Education Research in the Public Interest: Social Justice, Action, and Policy, edited by Gloria Ladson-Billings and Willaim F Tate (pp. 17-26). New York: Palgrave.

Australian Research Council (ARC). 2014. About ARC. Canberra: ARC. Available online at http://www.arc.gov.au; accessed on 1 December 2016.

Bailey, Reg. 2011. Letting Children be Children: Report of an Independent Review of the Commercialisation and Sexualisation of Childhood. London: The Stationery Office Ltd.

British Educational Research Association (BERA). 2004. Revised Ethical Guideline for Educational Research. Notts, UK: BERA.

BMBF: Federal Ministry of Education and Research. 2008. Framework Program for the Promotion of Empirical Educational Research. Berlin: BMBF.

Buckingham, David, Rebekah Wellett, Sarah Bragg, and Rachel Russell. 2010. External Research on Sexualized Goods Aimed at Children. Report to Scottish Parliament Equal Opportunities Committee. SP Paper 374. Edinburgh, UK: The Scottish Parliament.

Byron, Tanya. 2008. Safer Children in a Digital World: The Report of the Byron Review 2008. Nottingham, UK: Department for Children, Schools and Families, and the Department for Culture, Media and Sport.

Centre for Educational Research and Innovation (CERI). 2007. Evidence in Education: Linking Research to Policy. Paris: CERI, OECD.

CNRS: National Center for Scientific Research. 2014. Missions. Paris: CNRS.

Department for Education. 2013. Research Contract Terms and Conditions. London: Crown.

Department for Education. 2014. National Pupil Database. London: Department for Education. Available online at 
https://www.gov.uk/government/collections/national-pupil-database; accessed on 1 December 2016.

Department for Education. 2017. National Pupil Database: User Guide and Supporting Information. London: Department for Education. Available online at https://www.gov.uk/government/publications/national-pupil-database-user-guide-and-supporting-information; accessed on 2 February 2017.

EPPI-Centre. 2009. Home Page. London: EPPI-Centre, University College London. Available online at http://eppi.ioe.ac.uk/cms; accessed on 1 December 2016.

Economic and Social Research Council (ESRC). 2013. Britain in Magazine. Swindon, UK: ESRC.

European Union (EU). 2013. The EU Framework Programme for Research and Innovation. Luxembourg: Publications Office of the European Union.

Gogolin, Iigrid. 2011. EERQI Project Final Report. Dordrecht, Netherlands: European Educational Research Quality Indicators (EERQI) and Springer.

Hillage, James, Richard Pearson, and Allan Tamkin. 1998. Excellence in Research on Schools. Research Brief No. 74. London: Department for Education and Employment.

Hodkinson, Phil. 2004. "Research as a Form of Work: Expertise, Community and Methodological Objectivity.” British Educational Research Journal 30 (1): 9-26.

Ladson-Billings, Gloria, and William F. Tate (eds.). 2006. Education Research in the Public Interest: Social Justice, Action, and Policy. New York: Teachers College Press.

National Center for Educational Statistics (NCES). 2014. Home Page. Washington, DC: NCES. Available online at http://nces.ed.gov; accessed on 1 December 2016.

National Institute for Educational Policy Research (NIER). 2014. Position, Mission and Features. Tokyo: Ministry of Education, Culture, Sports, Science and Technology.

National Research Council (NRC). 2002 Scientific Research in Education. Washington, DC: National Academies Press.

NRC. 2014. DBASSE Mission. Washington, DC: Division of Behavioral and Social Sciences and Education (DBASSE), National Academies of Sciences, Engineering, and Medicine. Available online at http://sites.nationalacademies.org/DBASSE/DBASSE 067143; accessed on 1 December 2016.

National Science Committee (NSC). 2013. 2011 Policy Performance Report. Taipei: NSC, Ministry of Science and Technology.

Organisation for Economic and Co-operative Development (OECD). 2012. Assessment of Higher Education Learning Outcomes. Paris: OECD.

OECD. 2009. PISA Database. Paris: OECD.
OECD. 2014. PISA Database. Paris: OECD.

PISA in Taiwan. 2013 Overview. Taipei: PISA National Centre. Available online at http://pisa.nutn.edu.tw/; accessed on 1 December 2016.

Papadopoulos, Linda. 2010. Sexualisation of Young People Review. London: Institute of Education, University College London.

Research Councils UK (RCUK). 2014. Mission and Statement of Expectation on Economic and Social Impact. Brussels: RCUK.

Rush, Emma, and Andrea La Nauze. 2006. Letting Children be Children: Stopping the Sexualisation of Children in Australia. Discussion Paper No. 93. Manuka, ACT: The Australia Institute. Available online at http://www.tai.org.au/documents/dp_fulltext/DP93.pdf; accessed on 1 December 2016.

Saunders, Leslie. 2008. “'Preface' to Supplementary Issue: 'Evidence-based Education Policy': What Evidence? What Basis? Whose Policy?” Journal of Philosophy of Education 32 (S1): 14.

Simons, Helen. 1995. "The Politics and Ethics of Educational Research in England: Ccontemporary issues.” British Educational Research Journal 21 (4): 435-449.

Tooley, James, and Doug Darby. 1998. Educational Research - A Critique. London: OFSTED. 